\title{
Instrumentel intimitet
}

Den menneskelignende robot - androiden ${ }^{\mathrm{I}}$ - er en af de hyppigst forekommende (og populære) figurer i science fiction og kan, sammen med beslægtede fiktions-figurer som zombien, spøgelset og vampyren, siges at være en kulturel forhandlingsfigur for fremmedhed; en figur, hvis logik består i forskydning, og hvis mål er at præsentere det menneskelige som noget fremmedartet. I tilfældet androiden kan man sige, at der er tale om en fremmedhed, der skyldes et bestemt forhold til teknologien. Androiden og dens slægtninge bruges ofte til at italesætte bestemte lakuner, knudepunkter eller selvmodsigelser i det subjektive eller sociale.

Diskussionen af præcis hvilke roller vi i fiktionen - og dermed i større forstand i vores kollektive imaginarium - forestiller os, at androiden kan udfylde, bliver kun mere og mere relevant i takt med nye landvindinger inden for robotforskningen. Min motivation for at undersøge androidens skiftende konfigurationer i fiktionen stammer netop fra det overlap mellem fiktion, programmering og (daglig) anvendelse, som jeg finder kendetegnende: Selve de problematikker - især af etisk tilsnit - som kommer på banen ved konstruktionen af en faktisk eksisterende androide, udvikles ud fra et fælles sæt delte forestillinger om det kunstige, menneskeskabte liv. Mit argument er, at hvis vi ikke søger at gøre os klart, præcis hvad der foregår i det fiktive, risikerer vi ukritisk at lade problematiske forhold vandre med over i robotingeniørskabet. ${ }^{2}$ På trods af robotfiktionernes som oftest overdrevne, urealistiske og pseudovidenskabelige tilsnit bidrager de stadigvæk til det imaginarium, som robotingeniørerne også bebor. De er med til at optegne grænserne for, hvad vi forestiller os som ønskværdigt.

Androidens rolle kan naturligvis ikke én gang fikseres, men må forstås som en figur i konstant udvikling - en udvikling der finder sted i udveksling med det samfunds sociale imaginære, hvoraf den er rundet. ${ }^{3} \mathrm{Om}$ androiden forestilles som industriarbejder, utrættelig dræber eller godmodig socialarbejder, kommer an på dens kontekst. For at forstå androiden må vi, som Fredric Jameson påpeger, gå historisk til værks. Det er: 
4 not a psychological account we now seek, but rather a more historical one, which theorizes the conditions of possibility of these particular fantasies. (...) We need to get some idea of the specific situations and circumstances under which their composition is possible. (Jameson, 11)

I det følgende vil jeg fors $\varnothing$ ge at argumentere for, at der siden begyndelsen af det tyvende århundrede har eksisteret tre overordnede 'androide-paradigmer', og at vi for tiden befinder os i det tredje, hvor det intime forhold mellem menneske og androide står i centrum. Hvor tidligere perioders fiktion gerne iscenesatte androiden som en trussel i et slave- eller oprørsnarrativ, eller som en allegori for den menneskelige subjektivitet, er det nu som intime partnere at androiderne dukker op. Ikke forstået således at den 'traditionelle' fortælling om truslen fra robotterne - hvad forfatteren Isaac Asimov har betegnet som 'Frankenstein-komplekset' - er komplet forsvundet; både den fortsatte Terminator-serie samt en film som Ex Machina (2015) benytter sig i høj grad af androiden som antagonist. Man bør betragte de tre paradigmer som til en vis grad sameksisterende; og allerede August Viliers de l'Isle-Adams L'Éve future fra 1886 behandler i et vist omfang intimiteten mellem menneske og maskine.

At vi befinder os i dette tredje paradigme, er interessant set i lyset af den nu lurende mulighed for konstruktionen af maskiner, hvis primære funktion vil være som emotionelle partnere for bestemte udsatte grupper af borgere (såsom i ældreplejen og psykiatrien) - de såkaldte sociale robotter. Idealet i sidstnævnte er at skabe en maskine, som mennesker føler sig i stand til at være følelsesmæssigt engageret med; hvor udvekslingen ikke føles kunstig, men lige så 'autentisk' som relationen til et andet menneske. Med andre ord en form for intimitet.

Det, at androiden kommer til at blive set som en, der iværksætter en form for intimt rum med mennesket, er en central mekanisme i nyere værker såsom Alissa Nuttings roman Made for Love (2017). Men forudsætningen for idéen om et forhold mellem menneske og maskine er en forestilling om, at der overhovedet er en korrelation mellem de to - en forestilling der formuleres allerede i det tidlige 20. århundrede. For at anskueliggøre dette, kommer vi i det følgende også omkring værker af Ernst Jünger, Philip K. Dick og Isaac Asimov, der har været med til at bane forestillingsvejen for 'den menneskelige maskine', og som hver især har forsøgt at illustrere konsekvenserne af denne korrelation.

\section{Androiden som arbejder}

De menneskelignende maskiner, der møder os i det tyvende århundrede, er af et radikalt andet tilsnit end de former for kunstigt liv, der kom til live i fiktionen før 1 . verdenskrig, hvor man snarere bør tale om automata. Jeg tror, at det er vigtigt at adskille androiden fra automatonen: Hvor tidligere tiders forestillinger om kunstigt liv har været en magisk tildragelse - såsom golemen i den jødiske tradition - opstår der i det nittende århundrede en sammenvævning mellem det magiske og det videnskabelige som forklaring på skabelsen af et kunstigt liv (bl.a. Mary Shelleys Frankenstein fra 1818, E.T.A. Hoffmanns Der Sandmann fra 1817 og den førnævnte L'Éve future). ${ }^{4}$ 
Disse figurer bør adskilles fra det tyvende århundredes androider af den årsag, at der kun i sidstnævnte er tale om egentlig samlebåndsproduktion, hvilket er dét, der kæder dem sammen med masseindustrien. Androiden er fuldt og helt en forestillingsfigur, der udspringer af masseproduktionen, hvorimod de førnævnte figurer hos Shelley og Hoffman er helt og aldeles singulære fænomener, der skabes af enlige genier, hvis skaberkraft ikke skal associeres med den industrielle ingeniør, men med magikeren. Vi kan se et interessant overlap mellem disse tendenser i en film som Metropolis (1927), da 'hovedpersonen' - androide-kvinden - bliver bygget af videnskabsmanden Rotwang, der visuelt har mere til fælles med en troldmand; men samtidig iscenesætter filmen arbejdermassen som noget maskinelt og udviser derfor en bevidsthed om menneskets rolle i masseindustrien.

Den første registrerede brug af ordet 'robot' opstår i en periode, hvor netop menneskets ændrede livsvilkår som følge af dets omgang med teknologien er en central, social diskussion - i den tyske Weimar-republik talte man således om der Streit um die Technik ('kampen om teknikken'). Den moderne robots urfortælling er den tjekkiske forfatter Karel Čapeks teaterstykke R.U.R. (Rossum's Universal Robots) fra 1921. Čapeks fortælling er paradigmatisk for megen anden robotfiktion, i den forstand at den er en teknoficeret bearbejdelse af et oprørsmotiv. Hvad der gør historien særegen er ikke kun dens opfindelse af en helt ny betegnelse, men at den forsøger at iscenesætte mødet mellem menneske og teknologi på en ny måde, der gør det til en eksistentiel, frem for politisk, problematik. Selve roden til ordet 'robot' - robota, slavisk for arbejde/slaveri - betegner, at figuren fra første etymologiske instans er kædet sammen med arbejdet.

Dette fokus på arbejdets karakter kan også ses hos den tyske forfatter Ernst Jünger. På mange måder er Jünger eksemplarisk for diskussionen af teknologien ikke som et middel, men som noget ontologisk og som eksponent for det, som forskeren Jeffrey Herf har betegnet som 'reactionary modernism' - forsøget på at koble en højreorienteret traditionalisme med en teknologifascination. Jüngers tre essays fra starten af 1930'erne -Die Totale Mobilmachung, Der Arbeiter. Herrschafft und Gestalt og Über den Schmerz - beskæftiger sig alle med den nye type af industrielt arbejde som medvirkende til at udvikle et nyt menneske: arbejderen, hvis adelsmærke er den komplette sammensmeltning med den industrielle arbejdsproces. ${ }^{5}$

Et centralt begreb i Jüngers apparat er den 'organiske konstruktion'. Begrebet forsøger at illustrere, hvordan skellet mellem natur og teknologi ikke længere er gældende for mennesket, idet det teknologiske fuldt og helt definerer vores ontologiske horisont:

4 One belongs to an organic construction not through individual assent of the will - that is, by exercising an act of bourgeois freedom - but through a material interconnection, determined through the special work-character. To give a commonplace example, it is as easy to enter or resign from a political party as it is difficult to resign from the kind of association one belongs to as a consumer of electricity. (Jünger, 76)

Mennesket anvender ikke længere teknologien, men indgår i et forhold til den; et forhold, der skal ses som medvirkende til at gestalte den måde, verden fremtræder 
for os. Det, vi ser her, er, at mennesket transcenderer sit forhold til teknologien som middel; i stedet bliver teknologien medkonstituerende for selve det menneskelige.

Jüngers argument er, at tilsynekomsten af den industrialiserede arbejder (forstået som en ontologisk kategori) radikalt ændrer især det klasse- og partipolitiske system; arbejderen er ikke repræsentativ for den ene eller den anden klasse, men træder frem af historien som udtryk for netop menneskets nye forhold til teknikken. For dette menneske handler det om at være i et 'autentisk' forhold til industriprocessen snarere end at udvise loyalitet mod den ene eller den anden politiske dagsorden. Hvad der er interessant at tage med fra Jünger er retningen på hans analyse: Bevægelsen går fra menneske mod maskine, dvs. at maskinen er det ideal, som mennesket bør stræbe efter. Det enkelte individ skal opgive sine særtræk for at finde sin historiske sandhed ved at blive et tandhjul i industriens (og den industrialiserede krigs) struktur. ${ }^{6}$ Hvor R.U.R. og Metropolis som værker måske udtrykker en bekymret ambivalens over for erfaringen af, at mennesket påtager sig maskinens karakteristika, bør dette forhold for Jünger derimod tages med uforbeholden jubel: Menneskets ideal er maskinen. Det er her, vi kan se det første tilløb til den rolle, som androiden spiller i science fiction, nemlig at det maskinelle ikke er noget håndværksmæssigt, men et eksistentiale; det er en betegnelse for en specifik, historisk situation for mennesket i vesten.

\section{Subjektivitet og intimitet}

Arbejdet - og androiden som udelukkende en tjenende ånd - vedbliver ikke med at være ledestjernen for robotfiktionen. Som den amerikanske historiker Anson Rabinbach har argumenteret for i bogen The Human Motor, et studie af hvordan forholdet mellem menneske og arbejde er blevet forestillet og problematiseret fra og med den industrielle revolution, sker der en ændring i årene efter anden verdenskrig, hvad angår arbejde i den vestlige verden, hvor den 'tunge' industri udliciteres til den såkaldte 3. verdens lande. Rabinbach skriver, at "the centrality of work in European thought began to disappear as well" (Rabinbach 1992, 11) som følge heraf. Som blandt andre Henri Lefebvre og Herbert Marcuse har argumenteret for, ændrer menneskets forhold til den kapitalistiske samfundsorden sig, og der er derfor et øget behov for, at kultur- og samfundsanalysen fokuserer på individets fritid, som endnu et område, hvor der finder en fremmedgørelse sted. Dvs. frem for at betragte fritiden som hjemsted for en relativ åndsmæssig autonomi argumenterer en række tænkere for at inddrage denne sfære i samfundskritikken. Og denne bevægelse væk fra arbejdet som den vigtigste, sociale metafor får også konsekvenser for, hvad fiktionen fokuserer på.

Jeg vil argumentere for, at i og med at dette postindustrielle samfund begynder at udvikle sig, kommer androiden til at slippe sit ophav i det arbejdsrelaterede, som hos Jünger og Čapek, og begynder i højere grad at fungere som en figur, hvis funktion det er at stille spørgsmålstegn ved selve subjektiviteten som sådan. Når vi første gang møder robotten, er den mest af alt slutpunktet i en traditionel forestilling om slaven (der gør oprør), hvilket ordet også vidner om. Men så snart det mekaniske menneske ikke fremstår som noget radikalt andet, men som det mest tidssvarende 
udtryk for os selv (hvilket det i høj grad stadig er i dag - vi sanser og tænker gennem teknikken, dvs. som teknologiske væsener), skifter robotten også karakter og bliver til androiden. Den ophører med andre ord at være et symbol på mekaniseringen som sådan, og bliver i stedet til et symbol på os selv som mekaniserede væsener. Det er i denne forstand ikke længere arbejdet, der er omdrejningspunktet for maskinemennesket, men den måde hvorpå teknologien er blevet styrende for vores hele eksistens (jf. Martin Heideggers diskussion af ge-stell). Fordi det ikke længere kun er i forhold til sit arbejde, at mennesket kan siges at blive fremmedgjort, bliver det åndsløse og det hyperrationelle - med andre ord androiden - til en metafor for hele den menneskelige eksistens. Frem for kun at betegne menneskets forhold til en industrialiseret arbejdsproces, som man kunne argumentere for er det centrale i et værk som R.U.R., forsøger det snarere at italesætte eller problematisere, hvad der kendetegner mennesket - om det er rationaliteten, empatien eller dødeligheden, der er vores adelsmærke.

Det vil sige, at androiden i science fiction bruges til at forvirre grænsen mellem det menneskelige og det maskinelle - en forvirring eller grænseudviskning, der udgør den centrale problematik i Philip K. Dicks Do Androids Dream of Electric Sheep (1968). Heri stilles blandt andet spørgsmålet om, hvorvidt vores tendens til at tænke medfølelse som en udelukkende menneskelig kapacitet overhovedet gælder længere, eller om vi snarere i vores følelsesliv befinder os på maskinens niveau. ${ }^{7}$ På overfladen er Dicks bog en fortælling om dusørjægeren Deckards jagt på seks androider, der er undsluppet til Jorden fra kolonierne på Mars. Handlingen forløber over en dag, hvori det lykkes Deckard at opspore og destruere samtlige androider. Men det væsentlige er den forvirring og forandring, som Deckard undergår i løbet af fortællingen; en forandring, der trækker ham væk fra den rationelle og velfungerende dræbermaskine - $\mathrm{i}$ al væsentlighed, hans 'androidethed' - som vi præsenteres for i starten, til et menneske med en selvstændigt fungerende kapacitet for empati. I det hele taget er empatien, og måske mere grundlæggende det affektive, fortællingens benzin. Vi kan se det i det faktum, at den test som Deckard anvender til at konstatere om en person er et menneske eller en androide ("the Voight-Kampf test”), er en empati-test. Men det er lige så vel tydeligt i det, at hvor Deckard indledningsvist står i et rent instrumentelt forhold til sine følelser, ender han med at kunne føle empati for noget ikke-levende: en mekanisk frø, han finder i udkanten af San Francisco.

Et andet vigtigt spørgsmål, som også Jameson påpeger i sin analyse af Dick, er, hvorvidt androiden kan siges at være i besiddelse af subjektivitet. ${ }^{8}$ Det vil sige, at vi har at gøre med to sideløbende temaer, der begge omhandler subjektivitet (i hhv. mennesket og androiden), men hvor målet bliver at underminere nogen form for normativ forskel, der favoriserer mennesket. Ét aspekt af Dicks roman, der til en vis grad forsvinder i filmatiseringen Blade Runner, er, at der allerede fra åbningen bringes tvivl om, hvad der egentlig adskiller det moderne menneske som sådan fra androiden. I modsætning til filmen, hvor instruktøren Ridley Scott flere gange henviser til muligheden for, at Deckard selv er en androide, handler problematikken her snarere om, hvorvidt der overhovedet kan siges at være nogen større forskel på menneske og androiden, i kraft af førstnævntes instrumentelle forhold til sit eget følelsesliv. 
Da Deckard vågner ved siden af sin hustru Iran, er han indledningsvist glad og tilfreds takket være sit mood organ, et apparat hvormed man kan kontrollere sine følelsestilstande. Morgenens ro degenererer dog hurtigt til et skænderi, der centrerer sig omkring netop følelsernes instrumentalisering, da Iran insisterer på ikke at være glad, og derfor har undladt at indstille sit mood organ til en let og behagelig opvågnen:

Uf At his console he hesitated between dialing for a thalamic suppressant (which would abolish his mood of rage) or a thalamic stimulant (which would make him irked enough to win the argument).

'If you dial,' Iran said, eyes open and watching, 'for greater venom, then I'll dial the same. (...) She rose swiftly, loped to the console of her own mood organ, stood glaring at him, waiting. (...)

'I'll dial for both of us', Rick said, and led her back into the bedroom. There, at her console, he dialed 594: pleased acknowledgment of husband's superior wisdom in all matters. On his own console he dialed for a creative and fresh attitude toward his job. (Dick, 3-5)

Iran insisterer med andre ord på sin ret til at stå i et ikke-medieret eller autentisk forhold til sine følelser. Det bliver dog hurtigt klart, at også hun er afhængig af at være situeret i en bestemt teknologisk situation - Jüngers organiske konstruktion - for overhovedet at kunne føle; selv depression er i denne verden noget programmérbart, der har behov for teknologien for overhovedet at kunne formuleres og erfares:

46 'My schedule for today lists a six-hour self-accusatory depression,' Iran said.

'What? Why did you schedule that?' It defeated the whole purpose of the mood organ. 'I didn't even know you could set it for that,' he said gloomily. (Dick 1992, 2)

Som vi senere skal se i forbindelse med Alissa Nutting, iscenesætter Dick her en følelsernes ratio eller en instrumentel affektivitet, hvor en given indstilling af apparatet stimulerer den rette følelse - en time-management af følelseslivet. Koden til romanens sigte ligger her: Åbningsscenen optegner og underminerer fra start romanens skelnen mellem mennesker og androider; en forskel der, givet menneskets mangel på empatisk kapacitet, er en falsk konstruktion. Ikke mindst givet tilstedeværelsen i romanen af det kvasi-religiøse fællesskab Mercerisme, som via en såkaldt empatiboks giver hvert enkelt individ muligheden for at indgå i et virtuelt fællesskab med alle andre, der i dét øjeblik er tilsluttet maskinen.

Da Deckard senere i romanen investerer sine dusører i en ged til sig selv og Iran, er hendes første indskydelse, at de bør dele deres lykke med Mercerismens fælleskab:

Uf 'It would be immoral not to fuse with Mercer in gratitude,' Iran said. 'I had hold of the handles of the box today and it overcame my depression a little - just a little, not like this. (...) And I remember thinking how much better we are, how much better off, when 
we're with Mercer. Despite the pain. Physical pain but spiritually together' (...) In their living room, at the empathy box, Iran swiftly snapped the switch, her face animated with glowing gladness. (Dick, 77-78).

Interessant nok fors $\varnothing$ ger Deckard at lede sin hustru væk fra maskinen for at fortælle hende om de transformationer, han har gennemlevet. Han fors $\varnothing$ ger at etablere en mere autentisk intimitet mellem sig selv og Iran, hvorimod hun betragter det af teknologien medierede fællesskab som det autentiske.

Hvad vi kan se hos Dick er et opgør med en ontologisk skillelinje mellem det maskinelle og det menneskelige; i al væsentlighed er der, synes romanen at påstå, ikke nogen fundamental forskel, da androidernes rent rationelle tilgang til verden (og til hinanden) spejles i menneskets ikke mindre rationelle forhold til sine følelser og sine medmennesker. I den forstand udgør Dicks værk et afsætningspunkt for senere opgør med intimiteten i science fiction: Ved at fjerne forskellen og ved at vise hvordan Deckard og Iran forholder sig til ikke bare deres egne følelser, men også til intimiteten imellem dem, er banen kridtet op for, at denne bestemte type rationel intimitet kan komme i centrum. Deckards søgen efter de seks androider har altså som uventet konsekvens ikke kun at opløse den falske modsætning mellem menneske og androide, men også at gøre intimiteten til noget, der ikke er forbeholdt mennesket. For hvis vores emotionelle forhold til hinanden allerede er præget af teknologisk rationalitet, hvad skulle så forhindre en intimitet mellem menneske og maskine? Forskeren Jennifer Rhee har argumenteret for, at det er den tilbagevendende figur 'den schizoide androide' i Dicks fiktion, der udvisker grænsen mellem menneske og ting, men jeg vil argumentere for, at vi ikke har brug for en sådan figur - i Dicks fortællinger er det mennesket selv, der står for en sådan udviskning.

\section{Retten til døden}

Vi kan med fordel supplere analysen af Dicks roman med forfatteren Isaac Asimov. Asimov er bedst kendt for at formulere "The Three Laws of Robotics" (som han senere supplerede med en fjerde), som på mange måder er implicit eller eksplicit underforstået i al efterfølgende robotfiktion. ${ }^{9}$ Lovene er en måde for Asimov at sikre sine fortællinger mod at forfalde til science fiction-fortællingens klassiske motiv om "robotten som antagonist"; spørgsmålet er, hvorvidt denne lovmæssige treenighed på forhånd udelukker "robotten som protagonist", dvs. dens subjektiveringsproces.

I The Bicentennial Man, en af hans senere noveller, følger vi androiden Andrews færd mod at blive juridisk og eksistentielt anerkendt som menneske. Der sker her et skridt væk fra det masseproducerede og det generelle - Andrews status som person kan overhovedet kun komme på tale, fordi en anomali i hans kredsløb har gjort ham til en talentfuld kunstner: "The luck of the draw. Something in the pathways. (...) Nothing like this has ever been reported" (Asimov, 269). Det er grundlæggende set den samme søgen efter en klar skillelinje mellem menneske og androide, som hos Dick bliver vendt på hovedet, men frem for at betegne et generelt sammenfald mellem menneske og androide i følelsernes rationalisering, er Asimovs fortælling optaget af at definere en partikulær subjektivitet: 
Uf Andrew said cautiously: 'It all comes down to the brain, then, but must we leave it at the level of cells versus positrons? Is there no way of forcing a functional definition? Must we say that a brain is made of this or that? May we not say that a brain is something - anything - capable of a certain level of thought?'

'Won't work' said Li-Hsing. 'Your brain is man-made, the human brain is not. Your brain is constructed, theirs developed. To any human being who is intent on keeping up the barrier between himself and a robot, those differences are a steel wall a mile high and a mile thick. (Asimov, 307-308)

Hvad der er på færde her, kan man med rette betegne som en problematisering af, hvilke rammesætninger der finder sted forud for betegnelsen 'menneske'. ${ }^{\text {Io }}$ Som Asimov gør klart, handler Andrews kamp for anerkendelse i høj grad om, at visse former for intelligent liv vurderes som lavere end andre (konstrueret vs. organisk), men der er i novellen ikke tale om kollapset af en ontologisk grænse, kun med en særskilt overskridelse i én retning.

Hvor The Bicentennial Man for alvor bliver interessant, er, at Andrews anerkendelse i sidste ende knyttes sammen med døden: Andrew hyrer en robotkirurg til at foretage en operation, der giver hans kredsløb en begrænset levetid. Det kan ses som en fin iscenesættelse af Heideggers pointe om forholdet til døden, men lige så vel kan man ihukomme sig Judith Butlers begreb om 'sorgbarhed', hvis centrale argument er, at det er, fordi vi kan sørge over hinanden, at vi opfatter medmennesket som 'et liv'. Vores eksistens er ikke noget selvberoende, men bør mere betragtes som "levende felter af forskellighed, i den forstand at det 'at være påvirket af en anden' og 'at påvirke en anden' netop er en del af subjektets sociale ontologi, hvorfor 'subjektet' ikke så meget er en særskilt substans som en aktiv og transitiv mængde af indbyrdes forbindelser" (Butler, 183). ${ }^{\text {II }}$

I så henseende subjektiveres Andrew først i døden, dvs. idet han kan sørges over; idet hans eksistens bliver relationel på en transitiv og finit måde:

64 Andrew's thoughts were slowly fading as he lay in bed.

Desperately he seized at them. Man! He was a man! He wanted that to be his last thought. He wanted to dissolve - die - with that.

He opened his eyes one more time and for one last time recognized Li-Hsing waiting solemnly. (Asimov, 311)

Det er et på mange måder rørende øjeblik. Men hvis vi skulle følge Butlers argument til dørs, ville Andrew først opnå 'personhood', såfremt han også kunne sige sig fri fra de tre loves begrænsning - såfremt han kunne gøre skade på sig selv og andre:

Uf For Butler, human vulnerability, does not just speak to the capacity to be wounded, but also to the capacity to wound others. (...) The susceptibility to being harmed and to do harm is a constitutive characteristic of the human, one that underscores vulnerability and responsibility to others. (Rhee, 97) 
Sagt på en anden måde kan Andrew siges at være subjektiveret så længe hans ansvar for et andet menneske ikke er et frit påtaget ansvar (med den dertilhørende mulighed for fejlen)? Det er selve Andrews uskyldighed - og det at han ikke har et valg i den henseende - der afholder ham fra det menneskelige. Og i sidste ende også fra det intime.

\section{Hvad er et medmenneske?}

Her berører vi et essentielt element i diskussionen af androider og subjektivitet, nemlig tilstedeværelsen af noget u-menneskeligt (ikke ikke-menneskeligt) som konstitutivt for det menneskelige, som blandt andre Slavoj Žižek har påpeget: "the very core of being human is marked by a structure of immanent limitation, of not being 'fully' what one is, of one's identity being constitutively thwarted." (Žižek 2016, 28) Hvor Andrew måske nok ville kunne indlemmes juridisk i det menneskelige fællesskab, i og med at han som et rationelt tænkende væsen kan tage ansvar for sine handlinger, er det straks mere problematisk, hvad angår hans ubevidste eller rettere, hans mangel på samme. For netop denne totale selv-gennemsigtighed udelukker ham på forhånd fra den menneskelige erfaring: "The paradox is that if we take this limit or obstacle away and imagine a 'full' human being deprived of its perverse spin, we lose humanity itself." (Ibid.) Dette 'fulde' menneske er ironisk nok androiden, der uden at besidde denne fejlen ender med at fremstå som en monstrøsitet.

Androiden gestaltes ofte som den, der paradoksalt nok er mere menneskelig end mennesket - den, der i en given situation eksempelvis udviser mest medfølelse. Men som vi så vedrørende Asimov, er dette kun den ene del af ligningen: Medfølelse ville sagtens kunne opstå ud af en utilitaristisk beregning, lige så vel som grusomhed kunne. Men handlingen der opstår uden for individet selv, men alligevel tilhører det, er det kendetegnende træk ved mennesket - det der er i mig mere end mig selv. ${ }^{\text {I2 }}$ Det er derfor paradoksalt nok det faktum, at vi altid fejler i vores subjektiveringsproces, der egentlig udgør vores subjektivering.

Vores usikkerhed vedrørende androiden synes at skyldes en form for kategorifejl: Vi står over for noget, der tilsyneladende er ligesom os selv, men hvis overudviklede kognition modsvares af et følelsernes tomrum; noget selvbevidst, men udødeligt (eller i tilfældet Andrew: noget dødeligt, men uskyldigt). Som vi så hos Dick og Asimov, fungerer androidens tilstedeværelse som en problematisering af de rammesætninger, der bestemmer, hvad der tæller som liv, og hvad som ting. Vi kan anskueliggøre dette via filosoffen Martin Bubers begrebspar 'Ich-Du'/'Ich-Es'. I denne sammenhæng har jeg ingen intentioner om minutiøst at gennemgå Bubers begrebsapparat; jeg mener blot, at distinktionen mellem de to relationer er en konstruktiv måde at bearbejde den grænsezone, som androiden befinder sig i-i og med at den fordrer et kollaps af en sådan dikotomi.

I Bubers forståelse er der tale om, at forholdet til medmennesket ikke skal betragtes som erfaring, men som forhold: "Die Welt als Erfarung gehört dem Grundwort Ich-Es zu. Das Grundwort Ich-Du stiftet die Welt der Beziehung" (Buber, 6). Det vil sige, at den måde hvorpå vi er vendt mod tingene, og den relation der der- 
med finder sted, er af et radikalt andet tilsnit, end den måde hvorpå vi er vendt mod medmennesket. Hvis vi tager denne betragtning et skridt videre og kombinerer den med Butlers argument for det relationelle, kan vi sige, at subjektivitet ikke er noget på forhånd givet, men noget der opstår i rummet mellem Jeg'et og Du'et (skønt den spatiale metafor selvfølgelig til en vis grad er misvisende). Min person bliver først konstitueret, idet jeg er et 'Du' for en anden; idet jeg indtager en betydende plads i medmenneskets forståelseshorisont.

Problemet med androiden er dog, at den nægter at forholde sig til en sådan skarp adskillelse mellem ting og væsen; mellem $E s$ og $D u$. Buber påpeger, at vi per nødvendighed også indgår i Jeg-Det forhold til andre mennesker i det daglige, men når androiden er til stede som et sorgbart, subjektiveret individ, opfordrer den os til at tilgå den som et andet levende, tænkende og medfølende væsen. Skønt en ting synes relationen til androiden ikke at indstifte en erfaring, men et forhold. Det er bl.a. dette som Deckard må sande i løbet af jagten på androiderne: Efter 'pensioneringen' af androiden og operasangeren Luba Luft bliver han tvunget til at overveje muligheden af, at androidens bortgang rent faktisk udgør et affektivt tab (og dermed også et drab): "I can't anymore; I've had enough. She was a wonderful singer. The planet could have used her. This is insane" (Dick, 61). Som jeg vil komme ind på senere, er det netop, fordi vores definitioner af intimitet er under forandring, at adskillelsen mellem du og ting begynder at smuldre; og denne smuldren er det, som androiden bliver stand-in for. Viljen til at være intim med noget mekanisk er i dybere forstand emblematisk for vores vilje til at betragte medmennesket som en 'begærsopfyldningsmaskine'. Og forvirringen omkring androidens subjektive status er i sidste ende en forvirring omkring vores egen ditto.

Problemet kan siges at være, at idet vi mister den andens 'mangel', mister vi også muligheden for intimitet, fordi intimitet netop kræver et engagement med det i den anden, der undslipper os begge. Intimitet er et sats ud i den andens andethed, der forsøger at skabe et delt affektivt rum, som Lauren Berlant påpeger: "intimacy builds worlds; it creates spaces and usurps places meant for other kinds of relation. Its potential failure to stabilize closeness always haunts it persistent activity" (Berlant 1998, 282). For Berlant er intimiteten derfor kendetegnet ved lige dele skrøbelighed og 'for-meget-hed' - intimiteten er en stræben efter at gå over sine bredder, efter at annektere andre 'rum'. Når filosoffen Christopher Lauer skriver, at intimitet "demands a closeness beyond closeness" (Lauer 2016, 4), er det en indikation af, at det intime engagement ikke er med medmennesket, som vi kender (og elsker), men med noget 'andet' i vedkommende. Det er ikke bare alt det, vi kan tælle og optegne om vedkommende, men altid noget mere.

Det vil sige, at intimitet kun er mulig som en slags sekulært trosspørgsmål. Min intimitet med næsten er ikke til vedkommendes livshistorie, idiosynkrasier, 'sjæl' eller lignende, men altid til det i næsten, der er 'mere end sig selv' - med andre ord det ubevidste. På trods af at det som regel opfattes således, at jeg er intim med de mennesker, som jeg kender godt, er det i sidste ende ikke den andens velkendthed, vi engagerer os i, men i det potentielle kollaps, der altid hjemsøger det velkendte ("its potential failure"). Intimiteten er ikke kendetegnet ved hverken kendskab eller kategorisering (den-og-den følelse), men ved stræben. Som både Butler og Buber 
argumenterer Lauer for, at subjektivitet ikke er noget, der går forud for intimiteten, men derimod at denne stræben er det, der lægger grundlaget for subjektivitet: "it is not intimacy that is established between subjects, but subjectivity that emerges through intimacy (among other forms of recognition)" (Lauer, 45). Vi kan derfor sige, at intimiteten grundlægges på et engagement med det usikre element i medmennesket, og at det er ud af det deraf etablerede forhold ('Beziehung'), at subjektiviteten opstår som en delt erfaring af en mangel.

\section{Rigtige venner}

Dette bringer os til det tredje og sidste paradigme; det hvori vi kan siges at befinde os i dag.

Da Hanson Robotics i 2016 afslørede deres seneste humanoide robot, Sophia, var præsentationen ledsaget af en optimistisk vision for fremtiden inden for 'HumanRobot Interaction' (HRI). Som grundlæggeren David Hanson sagde: "I believe that artificial intelligence will evolve to the point where they will truly be our friends." ${ }^{\text {13 }}$

Af de foregående afsnit kunne det lyde som om, at en intimitet mellem menneske og robot hverken er mulig eller ønskværdig. Men det er netop her, at vi med Jameson bør være bevidste om de sociale konfigurationer, der omgiver det fiktive univers - for i en vis forstand er forestillingen om en sikker og rationel intimitet, hvor kun den ene af partnerne får noget ud af det, komplet på højde med sin tid. Det drejer sig ganske enkelt om, at intimiteten har ændret sig. At sige at en intimitet med noget mekanisk ikke er mulig grundet en mangel på ubevidsthed, fordrer spørgsmålet om, hvilken type intimitet vi så de facto opererer efter, givet at vi betragter sociale robotter som en reel mulighed.

Det er intimitetens gradbøjninger i den senmoderne, gennemteknologiserede verden, der er omdrejningspunktet for Alissa Nuttings roman Made for Love, hvor alle de væsentlige karakterer på den ene eller den anden måde er beskæftiget med at afklare deres respektive forhold til intimitet. Romanens centrale fortælling omhandler college-dropouten Hazel, der efter at have forladt sin mand Byron, den stenrige leder af et verdensomspændende, teknologifirma, flytter ind i sin fars trailer - uden at vide på forhånd, at faderen netop har solgt sin bil for at kunne købe den nyeste sex-robot til at forsøde sin alderdom.

Romanens sideløbende plot har hustleren Jasper som hovedperson, en yngre strandbums der lever af at forføre kvinder for dernæst at tiltuske sig deres penge. Dette underplot fungerer som en variation af det centrale motiv, i og med at Jaspers forhold til intimitet netop kommer til at fremstå instrumentelt. Han fortæller selv hvordan han betragter intimiteten: "A romantic relationship in which he didn't have a secret agenda held little appeal. In fact, the thought of vulnerability disgusted him" (Nutting 2017, 117). Det betyder, at Nutting ikke arbejder med en simpel dikotomi mellem på den ene side menneske-menneske relationer og på den anden menneske-robot, men derimod - hvilket gør hendes fortælling langt mere sofistikeret - snarere illustrerer, hvordan den instrumentelle tilgang til intimitet sniger sig ind i snart sagt alle karakterers forhold til omverdenen. I den forstand er Hazels fader på mange måder den mest reelle af karaktererne, på trods af hans lidet tilta- 
lende væsen, idet hans forhold til sit eget begær er komplet afklaret.

Hazels fader, Jasper og Byron indtager supplerende positioner i teksten, forstået på den måde at deres forhold til intimitet er præget af den samme instrumentelle 'stående-til-rådighed': Hvor faderen erhverver sig en sexrobot, hvis attributter han ikke er bleg for at udpege for Hazel ("And that's when the bathrobe was lifted. With a quick flip of the wrist, her father relieved Diane of all modesty"), og Jasper udelukkende betragter kvinder som et middel til at holde sin økonomi kørende, er Byrons syn på Hazel ikke i mindre grad præget af en rent logisk kalkule. Den eneste intimitet, Byron kan forestille sig, er at foreslå Hazel at få implanteret en mikrochip, hvorved deres to bevidstheder ville smelte sammen; hvilket er i fin tråd med det faktum, at Byron romanen igennem præsenteres som et 'androidt' menneske: "Byron's skin always felt refrigerated, and in sleep his pulse slowed down to a low, controlled speed that seemed akin to hibernation" (Nutting 2017, 181). Byron laver en ontologisk fejlslutning - ikke ulig David Hansons - når han forveksler viden med intimitet. I sit totalkontrollerede og gennemteknologiserede hus ('The Hub') kan han til enhver tid vide sig sikker på Hazels både fysiske og mentale helbred, da hun 24 timer i døgnet bliver scannet af diverse apparater:

Uf Sex with you would be redundant! she'd yelled at him once when he finally admitted there were multiple cameras and scanners and more in every room including the bathroom, that no second of her time inside The Hub had gone unrecorded. You're already inside my body with these fucking sensors! It was for safety and convenience, he'd stressed. It provided necessary data that technology relied on, technology that would supposedly keep them healthy, happy, and vital. I don't have a psychology degree, for example, he'd argue, but I can have your words and actions processed and analyzed with almost ninetyseven percent accuracy to reveal to me your current state of mind. How many couples can say that? (Nutting, 195)

For Byron er der simpelthen ikke noget usikkerhedselement forbundet med det at være intim med nogen, hvorved han misser relationens centrale element. At være intim er, i hans optik, at vide så meget som muligt om sin partner, så man kan handle på den logisk set mest hensigtsmæssige måde. Hvad Byrons projekt angående Hazel går ud på, er at domesticere den andethed, der danner grundlag for en intim relation. Han bytter usikkerhed for data, hvilket gør ham til romanens mest androide karakter.

Men som Lauer argumenterer for, er netop spørgsmålet om balance i direkte kontrast med det, der udgør grundstammen i intimiteten: "A world in which it is impossible to exceed boundaries, whether of proportion or propriety, is one in which intimacy is impossible" (Lauer, 37). Intimitet er altid en 'for-meget-hed', og en intimitet der ikke indeholder muligheden for overskridelse - eller man kunne lige så vel sige fejlfortolkning - er slet ikke en sådan.

I modsætning til romanens øvrige karakterer (i øvrigt alle mandlige) insisterer Hazel - på sin egen uduelige måde - på at bryde ud af den funktionsprægede verden, hun befinder sig i: 
Aunt Lena was dead, and Diane wasn't alive or sentient so it wasn't the most utilitarian introduction, but Hazel was sick of everything needing to have a function. Function was the only thing Byron cared about. His first question to everyone, always: 'What do you do?' by which he meant, What can you do for me? (Nutting 2017, 250)

Hazel kommer derfor til at stå som den, hvis dedikation til intimiteten ikke har noget 'rationelt' mål. Hun har ingen stopklods i forhold til, hvad der falder ind under hendes omsorgsområde: en plastikflamingo, faderens sexdukke og i sidste ende menneskeheden som sådan: "And what does that say about you, humanity, Hazel thought, that a grown woman whose arm is stuck down the throat of her elderly father's love doll feels sorry for you? It was not a spirited advertisement for mankind" (Nutting 2017, 249). Hun går med andre ord til verden udelukkende ud fra et 'Jeg-Du' Grundwort.

\section{No Demands, No Problem}

Dette bringer os videre til spørgsmålet om, hvad det så er for en 'instrumental rationalitet', som Byron, Jasper og faderen efterlever? Der er, som den amerikanske sociolog Sherry Turkle har påpeget, tale om 'companionship without demands', som den senmoderne måde at være sammen på. Turkle undersøger i bogen Alone Together, hvordan vores forhold til, og brug af, forskellige teknologier - herunder bl.a. sociale robotter - ændrer vores måder at forstå verden på. Hendes argument er blandt andet, at en forestilling om androiden som én, med hvem vi har en intim, følelsesfuld relation, fundamentalt ændrer, hvad vi forstår ved intimitet - fra at være en gensidigt givende relation, ændrer det sig til at være én, der kun arbejder en vej. Det tidligere omtalte aspekt ved intimiteten, dens skrøbelighed og dens evige potentiale for at fejle, er tilsyneladende ikke til stede her, hvilket mange robotudviklere synes at overse. ${ }^{\mathrm{I}}{ }^{4}$ Én ting er at lære en androide, hvilke sociale spilleregler der gælder for den intime relation, hvilket dels antager, at man ville kunne samle alle disse tråde til én, dels overser, hvordan begrebet om intimitet er kulturelt og geopolitisk betinget. Hvad der er mindst lige så vigtigt, er, at selve disse spilleregler ændrer sig, i takt med at flere og flere spillere - både på godt og ondt - inddrages. Det er med andre ord ikke nok blot at vise, at en androide har kapacitet for affektiv udveksling med et menneske, for idet denne relation kommer i stand, er det ikke længere det samme flygtige intimitetsbegreb, der gør sig gældende, men snarere noget i stil med en emotionel cost-benefit-analyse. Ændringen af intimitet kan derfor gå i to retninger, som vi så i Nuttings roman: Enten kan vi, som Hazel, forfølge det grænseoverskridende ved intimiteten ("It wasn't a position void of intimacy there on the ground with Diane" (Nutting 2017, 251)), eller vi kan tage forholdet til maskinen som ideal for vores forhold til medmennesket, og gøre vores intimitet instrumentel. Vi bør se kritisk på en intim relation, der som sit grundlæggende greb postulerer en form for 'sikker intimitet' - den følelsesmæssige pendant til 'sikker sex'. Det prækære er det essentielle ved det intime øjeblik - ikke kun i den forstand at relationen hvert øjeblik kan bryde sammen, men også som følge af det faktum, at enhver intim relation altid indebærer et forhold til den andens andethed. 
Ved at tage forholdet menneske-androide som paradigmatisk for det senmoderne forhold til medmennesket kan vi anskueliggøre nogle af de former, som intimiteten antager i dag. Om det før eller siden vil lykkes at konstruere en androide, der til punkt og prikke vil kunne udfylde rollen som intim partner, er i sidste ende underordnet; hvad der er interessant, er, at vi kan forestille os et sådant scenarie. Sagt på en anden måde: det essentielle er, hvordan androiden er konfigureret i vores samtidige robot-imaginarium, fordi det giver os en indikation af, at vores udvidelse af vores intimsfære også altid er en forandring heraf. At vi inkluderer flere væsener (i meget bred forstand) i vores omsorg, er som udgangspunkt positivt, men vi bør være opmærksomme på hvilke ændringer af selve begrebet intimitet, der finder sted undervejs i denne proces.

Diskussionen handler også i høj grad om, hvordan vi vælger at betragte subjektets forhold til sig selv og sit begær - ved vi selv, hvad vi begærer? Argumentet for sociale robotter er blandt andet muligheden for en partner, der kender os og som dermed ved, hvordan den kan gøre os glade. I én forstand en klar definition af, hvad intimitet betyder, nemlig et grundigt og åbent kendskab til hinanden, men som vi var inde på tidligere, er intimiteten ikke grundlagt på viden (som Byron synes at mene), men på en villighed til at interagere med det ukendelige. Den forestillede menneske-maskine intimitet støder ind i yderligere to problemer: dels er vi aldrig i stand til at formulere, og dermed videreformidle, hvad vi egentlig ønsker; og dels ville en maskine, der kunne udregne vores reelle ønsker via en eller anden form for analytisk algoritme, være helt og aldeles urovækkende - simpelthen fordi vi ikke ville kunne genkende, eller ønske at genkende, vores begær. Forestillingen om at den sociale robot ville være en meningsfuld partner i en ligeværdig, intim udveksling, er i det store og hele bundet op på en klassisk forestilling om det selvtransparente cogito, hvilket Asimovs Andrew er et klart eksempel på. Men problemet er, at androiden ikke har et ubevidste, hvilket i sidste ende er det, vi engagerer os i, når vi kaster os ud i intimitet med medmennesket. Intimitetens skrøbelighed, som Berlant påpeger, ligger nemlig præcis i det faktum, at vi aldrig blot er engageret i et andet cogito, men også altid i en anden ubevidsthed; det der er i den anden mere end hende selv.

\section{Tryg intimitet}

Jeg har i det foregående forsøgt at skitsere, hvordan androidens tilstedeværelse i den kollektive forestillingsverden kan siges at svare til en bestemt kulturel udfordring i en given historisk periode: hvordan intimitet bliver mulig (eller umulig) efter den digitale revolution. Set i dette lys er androiden den muligvis klareste figur for vores eksistentielle situation.

Her kan vi vende tilbage til David Hansons indledende optimisme på vegne af det gryende venskab mellem menneske og androide. For hvad der mangler fra Hansons syn på venskab, er naturligvis, at venner kan svigte; venskaber kan fejle. Og dette er muligvis den tænkningsmæssige fejl, der ligger til grund for forestillingen om, at androiderne kan være betydningsgivende partnere for mennesket. I og med at vi ikke hos androiden mødes af en mangel, er muligheden for en autentisk inti- 
mitet kortsluttet fra start. En androide kan give os, hvad vi vil have, den kan drage omsorg for os, imødekomme vores ønsker, få os til at føle os mindre ensomme - men den kan ikke det, som er grundlaget for den intime relation: Den kan ikke gøre os ontologisk usikre på os selv, samtidig med at denne usikkerhed kommer til at fungere som anstødsstenen til at grundlægge en subjektivitet, der er relationel. Vi kan sagtens frygte androidens sammenbrud, oprør eller monstrøse logik, men dette positionerer den som oftest kun som antagonist - ikke som affektiv partner. ${ }^{15}$

Men på trods af androidens shortcomings er det ikke ligegyldigt, at fiktionen er optaget af igen og igen at iscenesætte denne intimitet. Tværtimod er det essentielt at undersøge, hvorfor vi tilsyneladende ønsker en tryg intimitet, og under hvilke former den italesættes. At androiden er en stand-in for os selv er en selvindlysende sandhed - det interessante er, at det nu er vores intimitet, der i form af androiden er til genforhandling.

\section{Noter}

I Når jeg i det følgende insisterer på brugen af 'androide', er det for at adskille den menneskelignende, intelligente maskine fra eksempelvis de robotter, der anvendes på samlebånd. Begrebet 'androide' er dog behæftet med kønsmæssige problematikker ('androide' vs. 'gynoide)', men da jeg ikke har haft plads til at gå nærmere ind i denne diskussionen, har jeg valgt at holde mig til det velkendte begreb.

2 Et eksempel på dette ville netop være kønnede robotter ('engenderneering').

3 Begrebet 'det sociale imaginære' er lånt fra Charles Taylor.

4 Se eksempelvis Minsoo Kang: Sublime Dreams of Living Machines. The Automaton in the European Imagination (2011).

5 Dette er ikke en diskussion, der var begrænset til Tyskland; ligeledes i det unge Sovjetunionen blev maskinen hyldet som et ideal, bl.a. af de såkaldte 'maskinpoeter' som Aleksej Gastev og Vladimir Kirillov.

6 Det er i denne sammenhæng værd at medtage Jüngers problematiske politiske ståsted. Som del af den såkaldte 'konservative revolution' i mellemkrigsårenes Tyskland, udviser Jüngers tænkning stærke, fascistiske tendenser, og hans 'arbejder' kan således betragtes som et pansret, fascistisk subjekt.

7 Det giver også mening, at denne nye trope i robotfiktionen begynder at udvikle sig sideløbende med, at der i 1950'erne og 60'erne begynder at blive gjort fokuserede skridt i udviklingen af kunstig intelligens. Se evt. Elizabeth A. Wilson: Affect \& Artificial Intelligence.

8 Jameson: "(T)he age of Dick and Le Guin does not seem adequately characterized by a move from sociology to psychology either (...) 'Subjectivity' is a more capacious and less dogmatic category under which to range what we find at work in Dick's hallucinations as well as in Lem's cognitive paradoxes or Le Guin's antropological worlds" (Jameson, p. 92).

9 "1. A robot may not injure a human being, or, through inaction, allow a human being to come to harm. 2. A robot must obey the orders given it by human beings except where such orders would conflict with the First Law. 3. A robot must protect its own existence as long as such protection does not conflict with the First or Second Law." (Asimov, p. 15-16).

Io Den samme juridiske vinkel på problemet anvendes i øvrigt også i Star Trek Next Generation, hvor kaptajn Picard i afsnittet "The Measure of a Man" må argumentere for androiden Datas 'person-hed', for at forhindre at han bliver skilt ad. 
II Det er vel at mærke også noget, der er til stede hos Dick: Mercerismen kan siges at være et forsøg på at konstituere et 'sorgbart fællesskab'.

I2 Hvad der i den lacanianske psykoanalyse betegnes som extimité.

I3 Nyere eksempler på forestillingen om en nær og omsorgsfuld relation mellem menneske og androide kan blandt andet ses i filmen I Am Mother (2019), hvor en kvinde opfostres af en robot (og hvor det er mødet med et andet menneske, der er problematisk), samt Disney-filmen Big Hero 6 (2014). Disse film vender om på de gængse forhold for at forestille sig menneske-maskine forholdet som normalen for intimiteten.

I4 Blandt andre Cynthia Breazeal, skaberen af robotten Kismet.

I5 Såsom de genkommende androider i Alien-serien, som (kunne man mene) er seriens egentlige antagonister.

\section{Litteratur}

Asimov, Isaac (1997): “The Bicentennial Man”, i Robot Visions. Vista.

Berlant, Lauren (1998): “Intimacy: A Special Issue”, i Critical Inquiry, vol. 24, No. 2, Intimacy (Winter). The University of Chicago Press.

Buber, Martin (1995): Ich und Du. Reclam.

Butler, Judith (2015): Krigens rammer. Arena.

Dick, Philip K. (1992): Do Androids Dream of Electric Sheep. Ballantine Books.

Jameson, Fredric (2007): Archaeologies of the Future. The Desire Called Utopia and Other Science Fictions. Verso.

Jünger, Ernst (2017): The Worker: Dominion and Form. Northwestern University Press.

Kang, Minsoo (2011): Sublime Dreams of Living Machines. The Automaton in the European Imagination. Harvard University Press.

Lauer, Christopher (2016): Intimacy. A Dialectical Study. Bloomsbury.

Nutting, Alissa (2017): Made for Love. Ecco.

Rabinbach, Anson (1992): The Human Motor. Energy, Fatigue, and the Origins of Modernity. University of California Press.

Rhee, Jennifer (2018): The Robotic Imaginary. The Human and the Price of Dehumanized Labor. University of Minnesota Press.

Turkle, Sherry (2011): Alone Together. Why We Expect More from Technology and Less from Each Other. Basic Books.

Wilson, Elizabeth A. (2010): Affect \& Artificial Intelligence. University of Washington Press.

Žižek, Slavoj (2016): Disparities. Bloomsbury. 